\title{
A review on organic farming for sustainable agricultural production
}

\author{
Irfan Ashraf ${ }^{1}$, Ishtiaq Ahmad ${ }^{2 *}$, Muhammad Nafees ${ }^{2}$, Malik Muhammad \\ Yousaf $^{3}$ and Bashir Ahmad ${ }^{3}$ \\ 1. Department of Forestry, Range \& Wildlife Management, University College of Agriculture \& Environmental \\ Sciences, The Islamia University of Bahawalpur-Pakistan \\ 2. Department of Horticultural Sciences, University College of Agriculture \& Environmental Sciences, The Islamia \\ University of Bahawalpur-Pakistan \\ 3. Arid Zone Research Institute, Bahawalpur (PARC)-Pakistan \\ *Corresponding author's email: ishtiaq507@gmail.com
}

Citation

Irfan Ashraf, Ishtiaq Ahmad, Muhammad Nafees, Malik Muhammad Yousaf and Bashir Ahmad. A review on organic farming for sustainable agricultural production. Pure and Applied Biology. Vol. 5, Issue 2, 2016, pp277286. http://dx.doi.org/10.19045/bspab.2016.50036

\begin{tabular}{llll}
\hline Received: 11/02/2016 & Revised: 22/02/2016 & Accepted: 29/02/2016 & Online First: 04/03/2016 \\
\hline \hline
\end{tabular}

\section{Abstract}

In Pakistan, the most essential task is to produce sufficient and healthy food for the ever growing population. Therefore, to fulfill the food requirements of growing population, high yielding varieties are being cultivated that requires high unites of fertilizers and pesticides to meet the potential yield of cultivar. This combination has helped the country to be surplus in food but at the same time affecting the soil health. Massive use of fertilizers and pesticides cause serious threats to the environment and sustainability in agricultural productivity. Scientists, organizations and policy makers are emphasizing on high yield and good quality of agricultural produce on sustainable basis. Through organic farming high quality food could be produced without effecting the environment; however, a concern is whether large-scale organic farming will produce enough food for ever increasing population of Pakistan. Various organic products comprising rice, wheat, pulses, spices, oilseeds, fruits, vegetables, cereals, medicinal plants, and value-added products are produced in Pakistan. The production of these organic crops is reviewed with regard to sustainable organic forming in Pakistan as it is demand of consumer, due to health hazards.

Key words: Organic farming; Agriculture; Quality food; Soil health

\section{Introduction}

Organic farming is growing rapidly since last decade on sustainable with annual increase of $20 \%$ [1, 2], according to statistical analysis over 31 million hectares is under the organic forming with annual revenue of over 26 billion US \$, worldwide [3]. Although organic farming has been criticized for relying on the build-up of soil phosphorus $(\mathrm{P})$ and potassium $(\mathrm{K})$ by past fertilization before converting to organic [4]. Agriculture is the key sector for the socio economic development in developing countries like Pakistan. Ensuring food security, alleviating poverty and conserving the vital natural resources is critically important [5] and addressed through organic farming and various other means without spoiling natural resources. The major concern that compels scientists is that it very 
difficult to feed the ever increasing population with organic food [6]. Safe production and secure food supply is one of the major need of low income countries [7] to restore their reservoirs. The concept of food security therefore surrounds the components of agriculture, environment, employment income, marketing, health and nutrition and public policy [8]. In Pakistan total 8,138 million rupees used on the purchase of pesticide. In Pakistan it was also estimated that at Rs. 19.612 billion against import bill of Rs. 8.138 billion for 2003 [9].

Organic farming is a production system which avoids, or largely eliminates, the use of synthetic fertilizers, pesticides and growth regulators [10]. The objectives of environmental, social, and economic sustainability are the basics of organic farming [11]. Through the use of legumes and biological nitrogen fixation, active degradation of organic manure, including variety of crop debris and livestock wastes could be made. The beauty of organic farming is to maintain long term soil fertility by returning all the wastes to it chiefly through compost to minimize the gap between NPK addition and removal from the soil [12]. From the research it was concluded that the over usage and continuous application of chemical fertilizers have great concerns of human and environmental hazards, therefore, in developed countries farmers are encouraged to convert their prevailing farms into organic farm. Elevation in demand of organically produced commodities by consumer due health consciousness and public is ready to pay high prices for this produce [13]. The old farmers have their own rules and regulations to maintain the soil health as compared to modern agriculture [14]. While recent studies reveled that through the application of only organic inputs alone the nutritional requirements of the crop could not be fulfilled, the need to integrate the two forms in order to achieve better crop yields. The interaction between inorganic and organic matter may cause either decrease or increase soil nutrients, depending on the nutrient and planting material is a question [15].

\section{Organic matter source}

In organic farming the yield is slightly low as compared to modern intensive agriculture farming, use of synthetic fertilizer has not been helpful for sustainable production because it is often associated with reduced crop yield, soil acidity and nutrients imbalance [16]. Furthermore, fully dependence on inorganic source of fertilizer is not possible for the farmers, as it is not available at right time in remote areas of agricultural farms, other major issue is lack of technical knowledge about the inorganic fertilizers furthermore these are costly and common farmers are unable to use [17]. This is millstone for the agricultural scientists to enhance the crop productivity by utilization of organic source of fertilizers, ultimately results in increases the productivity of quality food sustainably as it improves the soil physical properties [18]. Currently, the utilization of these organic materials in soil fertility management in Africa is not common as compared to Asian countries [19]. The need to use renewable forms of energy and reduce cost of fustigation of crops has revived the use of organic fertilizers worldwide. Major concern is improvement of environmental condition and public health for advocating encouraging use of organic materials [20]. Field experiments confirms the effect of different sources of organic manure (Cow, Sheep and Poultry Manure) have significantly increase growth and yield of okra [21]. Any nutrient(s) deficiency in soil can cause a considerable decline in crop yield, especially under organic agriculture [22]. Nutrient deficiencies in crops can be 
prevented by using organic and inorganic nutrient sources [23]. However, the longterm use of increased amounts of only chemical fertilizers may degrade soil structure and deteriorate productive capacity of soils [24]. Judicious use of organic and inorganic nutrient sources is important to decrease the solitary dependence on chemical fertilizers for sustainable high crop production by minimizing nutrient losses to the environment and optimizing nutrient use efficiency [25]. Integrated use of organic amendments and chemical fertilizers may be a way to ensure sustainable agriculture and sustainable environment [26]. Low organic matter content is one of the most important contributing factor for poor fertility status of Pakistani soils. Bioslurry, a by-product from the biogas plant, can successfully be used to improve crop productivity and soil health [27]. Activity of mycorrhizae can be increased by the application of organic sources nutrients and other beneficial organisms in the soil and is also helpful in alleviating the increasing incidence or deficiency of macro and micronutrients [28]. Organically grown crops can give good reward to farmers like table pea (Pisum sativum L.), aromatic rice (Oryza sativa L.) and onion (Allium сера L.), as these crops frequently demanded by consumer of local, national and international markets due health concerns [29]. Manure collected from the animal sheds and wet straw, daily basis and stored for decomposition for the further application, this composted manure was applied, from this study results indicated that not only soil structure and fertility was improve but also water holding capacity and nutrient uptake efficiency was also improved, ultimately the crop productivity was significantly increased [30].

\section{Crop productivity and organic farming}

From the ancient times, with the application of organic matter (Farm Yard Manure) used for increase the crop yield on sustainable basis [31]. The high input agriculture has led to self-sufficiency in food grains but it has posed several new challenges. The conversion of modern agriculture into organic agriculture is now widely debated. Growing of high yielding varieties with indiscriminate use of fertilizers, poor water management practices and inefficient plantprotection measures in modern chemical intensive agriculture has resulted into degradation of lands owing to low crop yields with poor quality of produce [32]. The productivity of most of the crops is declining. Hence, conversion of modern chemically intensive agriculture to a more sustainable form of agriculture like organic farming appears to be an option for maintaining the desirable agricultural production in future [33]. Therefore, the use of locally available agro-inputs in agriculture by avoiding or minimizing the use of synthetically compounded agrochemicals appears to be one of the probable options to sustain the agricultural productivity. Generally, it is common thinking that yields of several crops reduce during the initial years under organic farming, but high market value of organically grown produces may be able to compensate the losses in yields [34]. Application of mustard oil cake or poultry manure alone gave better yield brinjal (Solanum melongena L.) compared to only chemical fertilizers. The organic matter content and availability of $\mathrm{N}, \mathrm{P}, \mathrm{K}$ and $\mathrm{S}$ in soil were increased by organic matter application [35]. There is substantial increase for grain yield in rice, with the application of organic matter [36]. It was found that with the application of $7.5 \mathrm{t} / \mathrm{ha}$ there is significant increase in the yield of rice. It is also found that there is considerable progress in grain yield of Chickpea [37]. Vegetables are highly responsive to organic sources of nutrients 
and profitable to farmers [38]. Response of chilli (Capsicum annuum L.) to vermicompost and observed that the application of vermicompost increased the microbial activities. Vermicompost has a positive effect on the performance of crops due to a higher number of branches and fruits [39]. Similarly excellent brinjal fruit yield (97 g/ plant) could be obtained; crop grown on vermin-compost [40], in case of sweet pepper (Capsicum annum L. var. grossum) with vermicompost there was tremendous increase in yield [41]. It was reported that in tomato, yield increased two and half times with the addition of organic matter as compared to inorganic source of nutrients [42]. while is also found that with the addition of vermi-compost in the growing media, resulted to four times increase number of fruits/plant in case of tomato [43]. On commercial basis it was found that application of vermin-compost @ $5 \mathrm{t} / \mathrm{ha}$ tremendous increase in the yield of tomato as compared to the inorganic fertilizers [44]. Mixture of soil mine spoil, coir pith vermin-compost (1:1:1) expressively improved number of leaf, plant height and root length in onion (Allium сера L.) [45]. Similarly head weight in cabbage $(700 \mathrm{~g})$ significantly increases but also yield $\left(38 \mathrm{tha}^{-1}\right)$ with the application of earthworm compost at 27 and $29 \mathrm{tha}^{-1}$ [46].

\section{Quality of produce in organic conditions}

For the agricultural scientists and policy makers the prime concern is environmental hazards and to develop such methods of which are helpful to produce quality food, for this basic step is search of alternate fertilizers which can replace the in-organic source of fertilizers; several organic materials have been used as fertilizers in organic crop production. But, usage of these (animal waste and urban sewage waste) materials in modern agriculture invites pollutions, such as heavy metals, chemical residues and parasites [47]. To overcome this problem, farmers have adopted a kind of biological fertilizer called Bokashi in Japanese, anaerobically fermented using oil seed sludge, rice bran and fish processing byproduct as materials. A microbial inoculate, including lactic acid bacteria, yeast and actinomycetes, is usually inoculated to materials before fermented. This kind of organic fertilizer is easily stored for long time without bite smell. However, the problem observed is the low nutrient availability at the early growth stage of crops even if the nutrient availability is hold longer than chemical fertilizers [48]. However, the researchers face the same problem that it is difficult for organic farming to get a yield similar to that by conventional farming. Two leafy vegetables were grown under greenhouse conditions and the dynamics of both the organic fertilizer and the plant growth were examined to elucidate the plant limiting factors and advantages of this organic fertilizer. Leaf-picking or leaf-peeling harvest method was adopted to prolong the growth and harvestable period. It has been proved that crop quality, especially the vegetables and fruits, is improved by organic fertilization [49]. The nutritional profile of leafy vegetables was studied including fallowing parameters like sugars contents, vitamin $\mathrm{C}$ and the ionic-nitrate, from the analysis the comparison between organic and inorganic grown vegetables was made. From results it was concluded that the concentrations of sugars and vitamin $\mathrm{C}$ were significantly higher but nitrate was lower in organic-fertilized than chemical-fertilized vegetables [50], in case of chilies it was observed that protein and carbohydrate concentration was significantly higher, grown on vermin composted vegetable waste [51]. Organic potato tubers farming may be expected to have significantly higher dry matter contents (19\%) that are considered good for processing into French 
fries without impairing the texture of the fries when concentrations exceed 23 per cent [52]. Similarly, application of FYM at $10 \mathrm{t} /$ ha alone increased the economic yield and quality parameters like hulling percentage, milling percentage, and protein and amylose content of rice cv. Saket-4 [53] it is observed that organically grown potato cv. Virgo having $66 \%$ higher yield than the conventional crop, whereas Raja yielded $47 \%$ [54].

\section{Soil fertility}

Soil fertility is basic demand that responsible for the productivity of all farming systems. Soil fertility is the ability of a soil to supply nutrients to crops [55], soil fertility is the ability of soil to produce crops [56]. The key indicator to assess the soil quality is organic matter contents as it affects the soil physical properties (porosity, water infiltration, bulk density and water holding capacity) directly [57, 58]. Confirmed that after decomposition of organic matter macro and micronutrients are released in the soil solution and available to plant for their growth. Higher crop productivity on sustainable basis is possible through the application of organic matter and improving soil health by developing favorable soil physical properties for plant growth and development [59, 60]. Soil reaction is declined due to addition of organic matter in fresh form that uptake the soil and plant nitrogen for the decomposition. While addition of inorganic nitrogen helps to speed up the soil reaction and decomposition of organic matter [61]. To raise the $\mathrm{pH}$ of the soil from 6.0 to 6.5 composet is used that leads reduction in the population of broad leaf weeds in field conditions $[62,63]$. To evaluate the efficiency of various organic materials like compost, Fram yard manure (FYM), Sesbania green manure alone and in combination with chemical fertilizer on the chemical properties and fertility status of soil. After the application of treatments, rice and wheat crops were grown. Soil samples were collected after the harvest of each crop from all the treatments, brought to the laboratory, prepared and analyzed for various parameters. It was noted that $\mathrm{pH}$ and SAR of the soil decreased in all the treatments from their original levels after both the crops. Role of compost was more pronounced when compared with FYM and Sesbania green manure [64]. Organic input in agricultural farm system is thought to enhance carbon sequestration by increasing soil organic matter content. Yet, the findings on the soil carbon concentrations increment in organically managed soil still remain controversial [65].

\section{Soil microbial activity}

Organic matter plays important role regarding soil productivity, several physical and chemical properties like improves soil water holding capacity, better aeration for germinating seeds and plant root development [66]. Because of continued cultivation, most of soils in Pakistan are deficit in organic matter [67]. Pakistani soils exhibit poor aggregate stability and are low in iron and aluminum contents. Out of a total of 33, 7714 samples analyzed in the Punjab, $96 \%$ of the samples were in the poor to medium range of organic matter and only $4 \%$ exhibited a moderate to adequate level. Micronutrient deficiency such as zinc is widespread in all rain fed areas. Continuous cultivation leads to decline in yield due to decrease in organic matter [68]. It is observed that addition of $0.4 \mathrm{t} / \mathrm{ha}$ paddy in to soil increases the soil productivity as microbial activity improves [69]. Soil physical and chemical properties improved with usage of compost ultimately enhance crop yield. Nutrient depletion \& low organic matter content in the Pakistani soils can be compensated only be by applying compost to these soils [70]. SAR and $\mathrm{pH}$ of the alkaline soil is decreased due to the addition 
of compost and other organic materials. As organic acids formed and due to release of $\mathrm{Ca}$ cause leaching of $\mathrm{Na}$, this phenomenon leads to slight increase in ECe of normal soil. The available amount of all the major plant nutrients ( $, \mathrm{P}, \mathrm{K}, \mathrm{Ca}$ and $\mathrm{Mg}$ ) and organic matter increased in the soil [71].

\section{Conclusion}

Through organic farming, provision of good quality food is possible without affecting soil health and environment on sustainable basis. There is need for the standardization of suitable organic sources for specific crop and hunting good market for earning good profit from the produce. The whole region as such cannot afford to go for organic at a time because of its commitments to insure food and nutritional security. This will provide ample opportunity for employment and bring prosperity and peace in the region. Organic farming ensures our soil to feed the nation for longer time on sustainable basis.

\section{Authors' contributions}

Conceived and designed the idea: I Ahmad \& M Nafees, Wrote the paper: I Ashraf, M M Yousaf \& B Ahmad

\section{Acknowledgement}

We are thankful to Directorate of Research, Innovation and Commercialization, The Islamia University of Bahawalpur, Pakistan for providing financial assistance to publish this review article in HEC recognize journal.

\section{References}

1. Avery A (2007). Going organic. Crops \& Soils. Amer Soc Agron 40: 8-12.

2. Lotter DW (2003). Organic agriculture. $J$. of Sustainable Agriculture, 21: 59-128.

3. Yussefi M, Willer H (2003). The World of Organic Agriculture-Statistics and Future Prospects. International Federation of Organic Agriculture Movements (IFOAM). 5th, revised edition

4. Greenland D (2000). Effects on soils and plant nutrition. In: Tinker, P.B. (Ed.). Shades of Green A review of UK
Farming Systems. Royal Agricultural Society of England, Warwickshire: 6-20.

5. Rothschild M (1998). The Butterfly Gard eners by Miriam Rothschild and elive farell, Great Britain: 128-130.

6. Moghtader M, Salari H \& Farahmand A (2011). Evaluation of the antifungal effects of rosemary oil and comparison with synthetic borneol and fungicide on the growth of Aspergillus flavus. J. of Ecology and the Natural Environment 3(6): 210-214.

7. Arshad S, \& Shafqat A (2012). Food Security Indicators, Distribution and Techniques for Agriculture Sustainability in Pakistan. International J. of Applied Science \& Technology 2: 137-147.

8. Johan P (1999). Anthropology of food: the social dynamics of food security. Cambridge, UK; Malden, a: Polity Press; Blackwell Publishers.

9. Khooharo AA, Memon RA \& Mallah MU (2008). An empirical analysis of Pesticide marketing in Pakistan. Pakistan Economic and Social Review 46: 57-74.

10. Howard A (1940). An Agricultural Testaments, Oxford University Press.

11. Stockdale EA, Lampkin NH \& Hovi M (2001). Agronomic and environmental implications of organic farming systems. Advances in Agronomy 70: 261-327.

12. Chhonkar PK (2002). Organic farming myth and reality. In Proceedings of the FAI Seminar on Fertilizer and Agriculture Meeting the Challenges, New Delhi, India.

13. Sofia PK, Prasad R \& Vijay VK (2006). Organic farming-tradition reinvented. Indian Journal of Traditional Knowledge, 1:139-142.

14. Chandra S \& Chauhan SK (2004). Prospects of organic farming in India. Indian Farming 52: 11-14.

15. Frankenberger WT \& Abdelmagid HM (1985). Kinetic parameters of nitrogen 
mineralisation rate of leguminous crops incorporated into soil. Plant and Soil 87: 257-271.

16. Ojeniyi SO (2000). Effect of goat manure on soil nutrients and okra yield in a rain forest area of Nigeria. Applied Tropical Agriculture 5: 20-23.

17. Chude VO (1999). Perspectives of fertilizer Use in the $21^{\text {st }}$ Century. In: Babalola O, Omoti U \& Isenmilla AI (Eds.): Management of Soil Resources of Nigeria for Sustainable Agricultural Production in the $21^{\text {st }}$ Century. Proceedings of the 25th Annual Conference of the Soil Science Society of Nigeria.

18. Somani LL \& Totawat KL (1996). Soil conditioners and amendments. Agrotech pub. Academy, Udaipur. ( $1^{\text {st }}$ Eds.): 28160.

19. Agboola AA \& Fagbenro JA (1985). Soil organic matter and its management in the humid tropics with particular reference to Nigeria. Proceedings. ISSS (Commission iv and vi organized by Society of soil Sci of Nig. 21st-26th July, 1985, Ibadan, Nigeria.

20. Maritus CHT \& Vlelc PLG (2001). The Management of Organic Matter in Tropical Soils: What are the priorities? Nutrients Cycling in Agro Ecosystems: 61: 1-16.

21. Tiamiyu RA, Ahmed HG \& Muhammad AS (2012). Effect of Sources of Organic Manure on Growth and Yields of Okra (Abelmoschus esculentus L.) in Sokoto, Nigeria. Nigerian Journal of Basic and Applied Science 20(3): 213-216.

22. Entz M H, Guilford R \& Gulden R (2001). Crop yield and soil nutrient status on 14 organic farms in the eastern portion of the northern Great Plains. Canadian Journal of Plant Science, 81, 351-354.
23. Graham RD \& Welch RM (2000). Plant food micronutrient composition and human nutrition. Commun. Soil Sci. Plant Anal 31: 1627-1640.

24. Doran JW \& Jones AJ (1996). Methods for assessing soil quality, vol. 49. SSSA special publication. Madison, WI: ASA.

25. Akhtar M, Naeem A, Akhter J, Bokhari SA \& Ishaque W (2011). Improvement in nutrient uptake and yield of wheat by combined use of urea and compost. Soil \& Environment 30: 45-49.

26. Ahmad R, Khalid A, Arshad M, Zahir ZA \& Naveed M (2006). Effect of raw (un-composted) and composted organic waste on growth and yield of maize (Zea mays L.). Soil \& Environment 25: 135-142.

27. Muhmood A, Javid S, Ahmad ZA, Majeed A \& Rafique RA (2014). Integrated use of bioslurry and chemical fertilizers for vegetable production. Pak J Agri Sci 51(3): 565-570.

28. Nambiar, KKM, Soni PN, Vats MR, Sehgal DK \& Mehta DK (1992). AICRP on long term fertilizer experiments," Annual Reports 1987-88 and 1988-89, IARI, New Delhi, India.

29. Kalyan S (2005). Development of sustainable farming system model for the Irrigated agro-ecosystem of Eastern UP, ICAR, Ad-hoc project," Final Annual Report, Department of Agronomy, Institute of Agricultural Science, Banaras Hindu University, Varanasi, India.

30. Timsina J \& Connor DJ (2001). Productivity and management of ricewheat cropping systems: issues and challenges. Field Crops Research, 69: 93-132.

31. Sharma AR \& Mitra BN (1990). Complementary effect of organic material in rice-wheat crop sequence. The Indian Journal of Agricultural Sciences 60: 163-168. 
32. Pradhan BK \& Mondal SS (1997). Integrated nutrient management for sustaining productivity and fertility building of soil under rice-based cropping system. Indian Journal of Agricultural Sciences 67: 307-310.

33. Modgal SC, Singh Y \& Gupta PC (1995). Nutrient management in ricewheat cropping system. Fertilizer News 40(4): 49-54.

34. Mahapatra BS, Singh SP, Rajesh A, Vishwakarma VK, Kumar, Anil, Singh RK, Ajay, Chilanda, Kishor \& Pandey CS (2006). Performance of lentil, chickpea and wheat under organic mode during initial years of conversion in relation to nutrient management practices. Journal of Eco-Friendly Agriculture. 1: 105-116.

35. Ullah MS, Islam MS, Islam MA \& Haque T (2008). Effects of organic manures and chemical fertilizers on the yield of brinjal and soil properties. $J$. Bangladesh Agril. Univ 6: 271-276.

36. Ranganathan DS \& Selvaseelan DA (1997). Mushroom spent rice straw compost and composted coir pith as organic manures for rice. Journal of the Indian Society of Soil Science 45(3): 510-514.

37. Singh KN, Prasad B \& Sinha SK (2001). Effect of integrated nutrient management on a typic haplaquant on yield and nutrient availability in a ricewheat cropping system. Australian Journal of Agricultural Research 52: 855-858.

38. Kalembasa D (1996). The effects of vermin-compost on the yield and chemical composition of tomato. Zeszyty Problemowe Postępów Nauk Rolniczych, 437: 249-252.

39. Singh G, Singh OP, Yadava RA, Singh PP \& Nayak R (1998). Response of rice (Oryza sativa) varieties to nitrogen levels in flash flood conditions. Indian Journal of Agronomy, 43: 506-510.

40. Tomar VK, Bhatnagar RK \& Palta RK (1998). Effect of vermin-compost on production of brinjal and carrot. Bhartiya Krishi Anusandhan Patrika 13: 153-156.

41. Kalembasa S \& Deska J (1998). The possibility of utilizing vermin-compost in the cultivation of radish and paprika. Annals of Agricultural University of Poznan 27: 131-136.

42. Renuka B \& Sankar CR (2001) Effect of organic manures on growth and yield of tomato. South Indian Hort 49: 216219.

43. Samawat S, Lakzian A \& Zamirpour A (2001). The effect of vermicompost on growth characteristics of tomato. Agricultural Science and Technology 15:83-89.

44. Arancon NQ, Edwards CA, Bierman P, Metzger JD, Lee S \& Welch C (2002). Effects of vermicomposts on growth and marketable fruits of field-grown tomatoes, peppers and strawberries, the 7th international symposium on earthworm ecology, Cardiff, Wales, 2002, Pedobiologia 47: 731-735.

45. Thanunathan K, Natarajan S, Sentikumar R \& Asulmurogan K. (1997) Effect of different sources of organic amendments on growth and yield of onion in mine spoil. Madras Agricultural Journal, 84: 382-384.

46. Oliveira AP, Ferreira DS, Casta CC, Silva AF \& Alves EV (2001). Utilization of cattle manure and earthworm compost in hybrid cabbage production. Horticulture Brasileira 13: 70-73.

47. McCalla TM, Peterson JR \& Lue-Hing C (1986). Properties of agricultural and municipal wastes. In: ASA CSSA SSSA (Editors), Soils for Management of 
Organic Wastes and Waste Waters. ASA, Madison. 11-46.

48. $\mathrm{Xu} \mathrm{HL} \mathrm{(2000).} \mathrm{Effects} \mathrm{of} \mathrm{a} \mathrm{microbial}$ inoculant and organic fertilizers on the growth, photosynthesis and yield of sweet corn. J Crop Prod 3: 183-214.

49. Larson A, Ching A, Messner F \& Messner H (2000). High quality, cost effective production of diverse horticultural crops grown organically: an individual case study in northwest Missouri, U.S.A. Acta Hort (ISHS) 536: 53-60.

50. Maynard DN \& Barker AV (1979). Regulation of nitrate accumulation in vegetables. Acta Hort (ISHS) 93: 153162.

51. Yadav RH \& Vijayakumari B (2004). Impact of vermicompost on biochemical characters of Chilli (Capsicum annum). Journal of Ecotoxicology and Environmental Monitoring 14: 51-56.

52. Haase T, Schüler C, Haase NU and Heb J (2007). Suitability of organic potatoes for industrial processing: effect of agronomical measures on selected quality parameters at harvest and after storage. Potato Research 50: 115-141.

53. Dixit G \& Gupta BR (2000). Effect of FYM, chemical and biofertilizers on yield and quality of rice and soil properties. J Indian Soc Soil Sci 48: 773-780.

54. Mourao I, Brito LM \& Coutinho J (2008). Cultivating the-future based-on science, volume-1: organic cropproduction," in Proceedings of the 2nd Scientific Conference of the International Society of Organic Agriculture Research ISOFAR, held at the 16th IFOAM Organic World Conference in Cooperation with the International Federation of Organic Agriculture-Movements IFOAM and the Consorzio ModenaBio, pp. 596-599.
55. Wild A (1993). Soils and the environment. An introduction. Cambridge University Press, Cambridge, UK.

56. Swift MJ \& Palm CA (2000). Soil fertility as an ecosystem concept: A paradigm lost or regained? In: Accomplishments and changing paradigm towards the 21 st Century.

57. Hudson BD (1994). Soil organic matter and available water capacity. J Soil Water Conserv 49: 189-194.

58. Minhas RS \& Sood A (1994). Effect of inorganic and organic on yield and nutrients uptake by three crops in rotation in aid alfisol. Journal of the Indian Society of Soil Science 42: 27260.

59. Gaur AC, Nilkantan S \& Dargan KS (2002). Organic Manures, ICAR, New Delhi, India.

60. Laxminarayana K \& Patiram (2006). Effect of integrated use of inorganic, biological and organic manures on rice productivity and soil fertility in ultisols of Mizoram. Journal of Indian Society of Soil Science 54: 213-220.

61. Rao NSS (1999). Organic matter decomposition. in Soil Microbiology, 255-270, Oxford \& IBH Publishing, New Delhi, India.

62. Bulluck LR, Brosius M, Evanylo GK \& Ristaino JB (2002). Organic and synthetic fertility amendments influence soil microbial, physical and chemical properties on organic and conventional farms. Applied Soil Ecology 19: 147160.

63. Rafay M, Hussain T, Ruby T, Rehman F, Abdullah M \& Ahmad I (2014). Role of weeds in creating agroecological stability. Pak J Agri Sci 51: 529-536.

64. Sarwar G, Naseem AR \& Mujeeb F (2009). Efficacy of various organic materials for improving chemical 
characteristics of Normal soil. Int $J$ Agric Appl Sci 1: 97-101.

65. Hongyeng L \& Agamuthu P (2014). Material substance flow analysis of carbon flux in an organic and a conventional vegetable farm. Pak J Agri Sci 51: 511-516.

66. Zia MS (1993). Soil fertility evaluation and management for flooded lowland rice soils of Pakistan. Ph. D. Dissertation Kyoto University, Japan.

67. Niazmi MI \& Khan NA (1989). The effect of soil crust on yield of maize crop on three soil families under rainfed condition. Pak J Soil Science 4: 25-29.

68. Juo ASR (1989). New farming systems in the wetter tropics. Experimental agriculture 25: 145-163.
69. Ponnamperuma FN (1984). Straw as a source of nutrients for wetland rice. Organic matter and rice IRRI, Los Banos, Philippines: 117-135.

70. Sarwar G, Hussain N, Mujeeb F, Schmeisky H \& Hassan G (2003). Biocompost for the improvement of soil characteristics and dry matter yield of Lolium perenne (grass). Asian Journal of Plant Sciences 2: 237-241.

71. Sarwar G, Schmeisky H, Hussain N, Suhammad S, Ibrahim M \& Safdar E (2008). Improvement of soil physical and chemical properties with compost application in Rice wheat cropping system. Pakistan Journal of Botany 40: 275-282. 